\title{
APLIKASI SISTEM MONITORING PELAPORAN PERKEMBANGAN KEGIATAN PENELITIAN DI BALAI PENELITIAN TANAMAN JERUK DAN BUAH SUBTROPIKA BATU
}

\author{
Dian Wahyuningsih'), Dwi Safiroh Utsalina'), Andri Prasetyo ${ }^{3)}$ \\ ${ }^{1)}$ Program Studi Teknologi Informasi, STMIK Pradnya Paramita Malang \\ ${ }^{2,3)}$ Program Studi Sistem Informasi, STMIK Pradnya Paramita Malang \\ Email: dian.wahyuningsih@stimata.ac.id ${ }^{1)}$ \\ Indonesia
}

\begin{abstract}
ABSTRAK
Balai Penelitian Tanaman Jeruk dan buah Subtropika (Balitjestro) merupakan lembaga dibawah kementerian Pertanian yang mempunyai tugas pokok untuk melaksanakan penelitian dalam rangka penguasaan inovasi teknologi tanaman jeruk dan buah subtropika. Setiap kegiatan penelitian disertai dengan laporan mulai dari rencana sampai dengan capaian hasil kegiatan, dan dilanjutkan dengan kegiatan monitoring (yang terdiri dari mengamati, mengontrol dan memverifikasi dengan cermat apa yang telah dikerjakan dalam suatu kegiatan penelitian). Selama ini sistem pelaporan perkembangan penelitian yang telah dilaksanakan di Balitjestro masih secara konvensional, yaitu peneliti menyerahkan lembar dokumen laporan yang dicetak kepada unit Yantek, jadwal pelaksanaan penelitian yang padat mengakibatkan kegiatan penyerahan laporan menjadi sering terlambat atau tertunda, dan akibat keterlambatan tersebut, unit (yantek) tidak dapat segera menyusun laporan untuk pimpinan, kecepatan laporan mempengaruhi evaluasi kinerja oleh pmpinan, selain kurang efisiennya proses penyerahan laporan, yantek juga kesulitan untuk memonitor laporan yang sudah atau belum terkirim. Dengan dibangunnya sebuah aplikasi monitoring dapat mempermudah pengguna (tim peneliti) dalam penyampaian laporan rencana kegiatan karena dapat dilakukan tanpa meninggalkan ruangan sehingga dapat menghemat waktu. dan Dapat memudahkan admin memonitor pelaporan yang sudah atau belum terkirim hanya dengan mengakses aplikasi monitoring pelaporan perkembangan kegiatan penelitian berbasis web. Pengembangan aplikasi menggunakan tahapantahapan pengembangan SDLC dengan model proses waterfall. Sedangkan bahasa pemrogramannya menggunakan PHP dengan MySQL sebagai databasenya.
\end{abstract}

Kata kunci: Aplikasi monitoring, balitjestro, kinerja peneliti, berbasis web, yantek

\section{ABSTRACT}

Balitjestro is an institution under the Ministry of Agriculture which has the task to research to master the technological innovation of citrus and subtropical fruits. Each study is accompanied by a report starting from the plan to the results of the activity. And followed by monitoring activities (which consist of observing, controlling, and verifying what is doing in a research activity). So far, the research development reporting system that has been at Balitjestro is still conventional. Namely, researchers submit printed report documents to the yantek unit. The busy research implementation schedule results in report submission activities being often late or delayed. As a result of this delay, the company (yantek) could not immediately compile a leadership report. The speed of the information affects the performance evaluation by leadership and the report submission process. It is also difficult to monitor messages that have been or have not be sent. With the construction of a monitoring application, it can make it easier for the user (the research team) to deliver the activity plan report because it can do it without leaving the room so that it can save time, and admin (yantek) can easily monitor messages have sent by simply accessing a web based monitoring application for reporting the development of research activities.

keywords: monitoring application, balitjestro, researcher performance, web based, yantek 


\section{PENDAHULUAN}

Balai Penelitian Tanaman Jeruk dan Buah Subtropika (Balitjestro) merupakan lembaga pemerintah di bawah Kementerian Pertanian yang bergerak dibidang penelitian buah-buahan subtropis. Yang menjadi tugas pokok Balitjestro adalah penelitian tanaman buah guna penguasaan inovasi teknologi (Badan Penelitian dan Pengembangan Pertanian, 2013) tanaman jeruk dan buah subtropika lainnya yang menjadi mandat Balai (jeruk, apel, anggur, lengkeng dan stroberi).

Setiap kegiatan penelitian harus diawali dengan memberikan laporan seputar rencana kegiatan dan diakhir penelitian dilengkapi dengan capaian hasil kegiatannya yang dilanjutkan dengan kegiatan monitoring dokumen laporannya. Dalam KBBI (Monitoring Dokumen Laporan, 2008), memonitor adalah mengawasi, mengamati, atau mengecek dengan cermat, terutama untuk tujuan khusus(Perezgonzalez, 2005). Bisa diartikan bahwa monitoring penelitian adalah kegiatan untuk mengawasi, mengamati, atau mengecek dengan cermat apa yang telah dikerjakan dalam suatu kegiatan penelitian yang digunakan sebagai bahan laporan.

Selama ini sistem informasi pelaporan perkembangan penelitian yang telah dilakukan peneliti Balitjestro masih disampaikan secara konvensional yaitu dengan menyerahkan lembar dokumen laporan yang dicetak kepada unit yantek. Ada beberapa hal yang menjadi kendala dalam penyampaian laporan tersebut yaitu 1)Waktu pelaksanaan kegiatan penelitian yang padat menyebabkan tertundanya peneliti dalam penyampaian laporan perkembangan kegiatan penelitian, 2) Ruang kerja antara peneliti dan unit yantek tidak berada pada satu ruangan yang sama, bahkan berbeda gedung bangunan, 3) Unit yantek harus menunggu peneliti datang menyerahkan hasil laporannya guna menyusun bahan laporan untuk pimpinan, 4) Unit yantek mencatat dokumen laporan hasil penelitian dengan aplikasi excel yang berfungsi pula sebagai alat monitoring pelaporan yang telah terkumpul.

Sistem informasi monitoring telah banyak digunakan untuk mendukung pengelolaan sumber daya dalam organisasi atau perusahaan (Mardiani, 2013) (Afriyan, 2011) (Dita Pahang Putra, 2010) (Nurhayati \& Feliciano Waha, 2012) pelaporan kegiatan penelitian yang telah dilaksanakan selama ini masih kurang tepat untuk diterapkan karena kurang efisien dari segi waktu dan tenaga, dalam mengurangi dampak dari permasalahan yang terjadi diantaranya perlu adanya pendekatan dalam Menyusun sistem informasi monitoring(Heli Setyawan \& Munari, 2020), (Rizal HIkmah \& Andarsyah, 2020) termasuk perlu adanya pendekatan dalam peningkatan efisiensi, seperti yang telah diteliti oleh(leonove \& Boiko, 2019) . Perlunya kemudahan peneliti dalam menyampaikan laporan tepat waktu akan mempercepat kinerja unit yantek dalam menerima dokumen laporan penelitian dan mampu meningkatkan pelayanan(Daniel et al., n.d.). Kecepatan dalam penyampaian laporan akan memudahkan pula pimpinan dalam mengevaluasi dan memberikan arahan apabila perkembangan penelitian tidak/kurang sesuai dengan jadwal yang telah disusun sebelumnya. Dengan sistem informasi pelaporan perkembangan penelitian yang akan dikembangkan, memungkinkan monitoring pelaporan perkembangan hasil penelitian dilakukan dengan lebih baik, karena disamping telah dilengkapi dengan monitoring, aplikasi ini juga digunakan berbasis web (Mardiani, 2013) (Cortinas et al., 2017) sehingga dimanapun user berada yang bersangkutan dapat menggunakannya.

\section{METODE PENELITIAN}

Pelaksanaan penelitian yang dilaksanakan di Balitjestro, selama 4 bulan menggunakan Teknik pengumpulan data (1) Observasi, yang berhubungan dengan pelaksanaan penyampaian laporan rencana kegiatan yang terjadi (2)Wawancara, tanya jawab secara langsung dengan unit Yantek dari Balitjesro (3) Studi Pustaka, memanfaatkan data yang berhubungan dengan kegiatan penelitian.

\subsection{Perancangan Sistem}

Arsitektur aplikasi ini menggunakan aplikasi pemodelan UML. Pada tahap perancangan ini juga akan dijabarkan dengan use case, Class diagram dari Aplikasi ini.

\subsubsection{Use Case}

Use case untuk menggambarkan konsep hubungan antara sistem monitoring dengan pihak luar terdapat pada gambar 1 . 


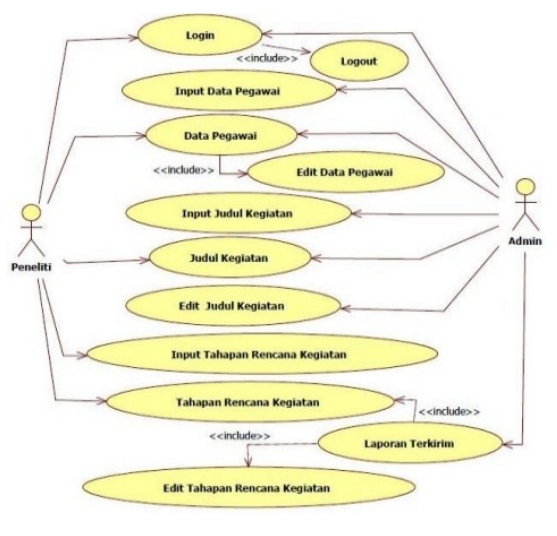

Gambar 1. Use case diagram

Pada use case gambar 1 dapat dideskripsikan hal-hal sebagai berikut: (1) Satu sistem yang mencakup seluruh kegiatan yang sedang berjalan.(2) Terdapat 2 aktor yang melakukan kegiatan tersebut, yaitu peneliti dan admin. (3) Ada 12 use case yang bisa dilakukan oleh aktor-aktor tersebut, meliputi: login, input data pegawai, data pegawai, edit data pegawai, input judul kegiatan, judul kegiatan, edit judul kegiatan, input tahapan rencana kegiatan, laporan terkirim, tahapan rencana kegiatan, edit tahapan rencana kegiatan, dan logout.

\subsubsection{Class Diagram}

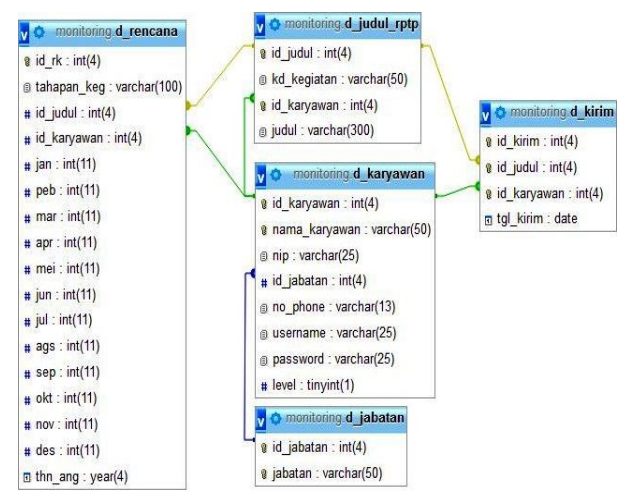

Gambar 2. Class Diagram

\subsection{Arsitektur mesin sistem}

Dalam penelitian ini menggunakan OOAD (Object Oriented Analyst Design) adalah metode analisis yang memeriksa requirements pada suatu kelas dan objek yang ditemui dalam ruang lingkup permasalahan yang mengarah pada arsitektur Software yang didasarkan pada manipulasi objekobjek sistem atau subsistem. Terdapat beberapa konsep dalam OOAD yaitu kelas, object, metode, atribut, Atribut, Abstraksi,dll.

\section{HASIL DAN PEMBAHASAN}

3.1. Testing/implementasi Rancangan Interface Rencana pengujian sistem baru yang telah berhasil dibangun dilaksanakan dengan menggunakan metode Black Box (Haryono et al., n.d.) pada user dan administrasinya. Hasil pengujian harus menunjukkan bahwa sistem ini telah bekerja sesuai dengan tujuan penelitian dan berjalan sesuai dengan apa yang diharapkan serta tanpa masalah (Eka Kumala et al., n.d.) (Afrianto \& Setiyadi, 2019) dimana setiap statement pada sistem telah dieksekusi paling tidak satu kali selama pengujian dan semua kondisi logis telah diuji dan berhasil.

Terdapat beberapa pengujian sistem yang dilakukan pada sistem ini terdapat pada tabel 1

Tabel 1. Rencana pengujian sistem

\begin{tabular}{|c|c|c|c|}
\hline No & Item Uji & $\begin{array}{c}\text { Detail } \\
\text { Pengujian }\end{array}$ & $\begin{array}{c}\text { Jenis } \\
\text { Pengujian } \\
\end{array}$ \\
\hline \multicolumn{4}{|c|}{ Administrasi } \\
\hline 1. & Login & $\begin{array}{l}\text { Verifikasi nama } \\
\text { dan kata kunci }\end{array}$ & Black box \\
\hline \multirow{3}{*}{2.} & \multirow{3}{*}{$\begin{array}{l}\text { Data } \\
\text { Pegawai }\end{array}$} & $\begin{array}{l}\text { Insert data } \\
\text { pegawai }\end{array}$ & Black box \\
\hline & & $\begin{array}{l}\text { Update data } \\
\text { pegawai }\end{array}$ & Black box \\
\hline & & $\begin{array}{l}\text { Delete data } \\
\text { pegawai }\end{array}$ & Black box \\
\hline \multirow{3}{*}{3.} & \multirow{3}{*}{$\begin{array}{l}\text { Judul } \\
\text { Kegiatan }\end{array}$} & $\begin{array}{l}\text { Insert data } \\
\text { pegawai }\end{array}$ & Black box \\
\hline & & $\begin{array}{l}\text { Update data } \\
\text { pegawai }\end{array}$ & Black box \\
\hline & & $\begin{array}{l}\text { Delete data } \\
\text { pegawai }\end{array}$ & Black box \\
\hline \multirow{3}{*}{4.} & \multirow{3}{*}{$\begin{array}{l}\text { Laporan } \\
\text { Terkirim }\end{array}$} & $\begin{array}{l}\text { Detil laporan } \\
\text { terkirim }\end{array}$ & Black box \\
\hline & & $\begin{array}{l}\text { Update data } \\
\text { pegawai }\end{array}$ & Black box \\
\hline & & $\begin{array}{l}\text { Delete data } \\
\text { pegawai }\end{array}$ & Black box \\
\hline \multicolumn{4}{|c|}{ User (Peneliti) } \\
\hline 1. & Login & $\begin{array}{l}\text { Verifikasi nama } \\
\text { dan kata kunci }\end{array}$ & Black box \\
\hline 2. & $\begin{array}{l}\text { Data } \\
\text { Pegawai }\end{array}$ & $\begin{array}{l}\text { Update data } \\
\text { pegawai }\end{array}$ & Black box \\
\hline \multirow{2}{*}{3.} & \multirow{2}{*}{$\begin{array}{l}\text { Judul } \\
\text { kegiatan }\end{array}$} & $\begin{array}{l}\text { Input rencana } \\
\text { kegiatan }\end{array}$ & Black box \\
\hline & & $\begin{array}{l}\text { Detil rencana } \\
\text { kegiatan }\end{array}$ & Black box \\
\hline
\end{tabular}

\subsection{Kegiatan pengujian sistem}

Kegiatan pengujian sistem ini, menggunakan jenis pengujian alpha. Berdasarkan rencana pengujian yang telah disebutkan di tabel 2 maka dapat dilakukan kegiatan pengujian sistem sebagai berikut.

\subsubsection{Pengujian sistem pada administrasi}

\section{a. Pengujian sistem login}

Kegiatan pengujian sistem login dilakukan dengan memasukkan beberapa variasi pengujian. Untuk pengujian dapat dilihat dapat dilihat pada tabel 2 : 
Tabel 2. Pengujian login

\begin{tabular}{|c|c|c|c|c|c|}
\hline \multicolumn{6}{|c|}{ Kasus dan Hasil Uji } \\
\hline \multicolumn{3}{|c|}{ Data Masukan } & \multirow{2}{*}{ Yang Diharapkan } & \multirow{2}{*}{ Hasil Pengujian } & \multirow{2}{*}{ Kesimpulan } \\
\hline No & Variabel & Masukan & & & \\
\hline \multirow{2}{*}{1.} & Nama & kosong & \multirow{2}{*}{ Login gagal } & \multirow{2}{*}{ Login gagal } & \multirow{2}{*}{ Pengujian sukses } \\
\hline & Kata Kunci & kosong & & & \\
\hline \multirow{2}{*}{2.} & Nama & kosong & \multirow{2}{*}{ Login gagal } & \multirow{2}{*}{ Login gagal } & \multirow{2}{*}{ Pengujian sukses } \\
\hline & Kata Kunci & 123 & & & \\
\hline \multirow{2}{*}{3.} & Nama & admin & \multirow{2}{*}{ Login gagal } & \multirow{2}{*}{ Login gagal } & \multirow{2}{*}{ Pengujian sukses } \\
\hline & Kata Kunci & kosong & & & \\
\hline \multirow{2}{*}{4.} & Nama & admin & \multirow{2}{*}{ Login sukses } & \multirow{2}{*}{ Login sukses } & \multirow{2}{*}{ Pengujian sukses } \\
\hline & Kata Kunci & 123 & & & \\
\hline \multirow{2}{*}{5.} & Nama & baru & \multirow{2}{*}{ Login gagal } & \multirow{2}{*}{ Login gagal } & \multirow{2}{*}{ Pengujian sukses } \\
\hline & Kata Kunci & kosong & & & \\
\hline \multirow{2}{*}{6.} & Nama & baru & \multirow{2}{*}{ Login sukses } & Login sukses & \multirow{2}{*}{ Pengujian sukses } \\
\hline & Kata Kunci & baru & & & \\
\hline
\end{tabular}

Dapat dijelaskan bahwa pengujian sistem login pada tabel 2 digunakan untuk mengetahui bagaimana administrasi dapat masuk ke halaman utama aplikasi. Untuk dapat masuk ke halaman utama administrasi terlebih dahulu harus terdaftar di dalam database aplikasi.

\subsubsection{Pengujian Data Pegawai}

Pengujian data pegawai meliputi insert data pegawai, update data pegawai, serta delete data pegawai yang dilakukan dengan memasukkan variasi pengujian. Kegiatan pengujian sistem insert, update, dan delete terdapat pada tabel 3.

Tabel 3. Pengujian insert, update, dan delete data pegawai

\begin{tabular}{|c|c|c|c|c|c|}
\hline \multicolumn{6}{|c|}{ Kasus dan Hasil Uji } \\
\hline \multicolumn{3}{|c|}{ Data Masukan } & \multirow[t]{2}{*}{$\begin{array}{c}\text { Yang } \\
\text { Diharapkan }\end{array}$} & \multirow[t]{2}{*}{ Hasil Pengujian } & \multirow[t]{2}{*}{ Kesimpulan } \\
\hline No & Variabel & Masukan & & & \\
\hline \multirow{7}{*}{1.} & NIP & kosong & \multirow{7}{*}{$\begin{array}{l}\text { Gagal } \\
\text { menyimpan } \\
\text { data baru }\end{array}$} & \multirow{7}{*}{$\begin{array}{l}\text { Penyimpanan } \\
\text { gagal }\end{array}$} & \multirow{7}{*}{$\begin{array}{l}\text { Pengujian sukses, } \\
\text { data gagal disimpan } \\
\text { karena ada field yang } \\
\text { kosong }\end{array}$} \\
\hline & Nama Pegawai & baru & & & \\
\hline & Jabatan & kosong & & & \\
\hline & No. Telephone & 0813555777333 & & & \\
\hline & Username & baru & & & \\
\hline & Password & baru & & & \\
\hline & Hak Akses & peneliti & & & \\
\hline \multirow{7}{*}{2.} & NIP & 20170530.201706 .1 .013 & \multirow{7}{*}{$\begin{array}{l}\text { Sukses } \\
\text { menyimpan } \\
\text { data baru }\end{array}$} & \multirow{7}{*}{$\begin{array}{l}\text { Penyimpanan } \\
\text { sukses }\end{array}$} & \multirow{7}{*}{$\begin{array}{l}\text { Pengujian sukses, } \\
\text { karena seluruh field } \\
\text { terisi. }\end{array}$} \\
\hline & Nama Pegawai & baru & & & \\
\hline & Jabatan & peneliti & & & \\
\hline & No. Telephone & 0813555777333 & & & \\
\hline & Username & baru & & & \\
\hline & Password & baru & & & \\
\hline & Hak Akses & peneliti & & & \\
\hline \multirow{7}{*}{3.} & NIP & 20170530.201706 .1 .013 & \multirow{7}{*}{$\begin{array}{l}\text { Sukses } \\
\text { menyimpan } \\
\text { data yang } \\
\text { diedit }\end{array}$} & \multirow{7}{*}{$\begin{array}{l}\text { Penyimpanan } \\
\text { sukses }\end{array}$} & \multirow{7}{*}{ Pengujian sukses } \\
\hline & Nama Pegawai & Baru diganti & & & \\
\hline & Jabatan & peneliti & & & \\
\hline & No. Telephone & 0813555777212 & & & \\
\hline & Username & Baru & & & \\
\hline & Password & Baru07 & & & \\
\hline & Hak Akses & peneliti & & & \\
\hline \multirow{7}{*}{4.} & NIP & 20170530.201706 .1 .013 & \multirow{7}{*}{$\begin{array}{l}\text { Sukses } \\
\text { menghapus } \\
\text { data }\end{array}$} & \multirow{7}{*}{$\begin{array}{l}\text { Hapus data } \\
\text { sukses }\end{array}$} & \multirow{7}{*}{ Pengujian sukses } \\
\hline & Nama Pegawai & Baru diganti & & & \\
\hline & Jabatan & peneliti & & & \\
\hline & No. Telephone & 0813555777212 & & & \\
\hline & Username & Baru & & & \\
\hline & Password & Baru07 & & & \\
\hline & Hak Akses & peneliti & & & \\
\hline
\end{tabular}


Pada tabel 3 dapat dijelaskan bahwa pengujian insert data pegawai dapat digunakan untuk menambahkan data pegawai baru. Field-field pada form input harus terisi semua tanpa ada yang kosong, agar data yang baru ditambahkan dapat tersimpan dalam database. Update data pegawai diperlukan untuk menyesuaikan dengan data terbaru jika ternyata ada perubahan data. Untuk melakukan perubahan data pegawai, admin dapat langsung memilih tombol edit pada view data pegawai yang dikehendaki.

Delete/hapus data juga dapat dilakukan dengan memilih data yang dikehendaki. Penghapusan data hanya boleh dilakukan pada saat-saat awal proses penambahan data pegawai. Penghapusan pegawai tidak disarankan apabila pegawai tersebut sudah pernah penjadi penanggung jawab suatu kegiatan penelitian karena dapat mempengaruhi sistem aplikasi. Untuk menghapus data pegawai, admin dapat langsung memilih tombol hapus pada view data pegawai yang dikehendaki.

\subsubsection{Pengujian Judul Kegiatan}

Pengujian judul kegiatan meliputi insert judul kegiatan, update judul kegiatan, serta delete judul kegiatan dilakukan dengan memasukkan variasi pengujian. Kegiatan pengujian sistem insert, update, dan delete terdapat pada tabel 4.

Tabel 4. Pengujian insert, update, dan delete judul kegiatan

\begin{tabular}{|c|c|c|c|c|}
\hline \multicolumn{5}{|c|}{ Kasus dan Hasil Uji } \\
\hline \multicolumn{2}{|c|}{ Data Masukan } & \multirow[t]{2}{*}{ Yang Diharapkan } & \multirow[t]{2}{*}{$\begin{array}{c}\text { Hasil } \\
\text { Pengujian } \\
\end{array}$} & \multirow[t]{2}{*}{ Kesimpulan } \\
\hline Variabel & Masukan & & & \\
\hline Kode kegiatan & 1804.007 .013 & \multirow{3}{*}{$\begin{array}{l}\text { Gagal menyimpan } \\
\text { data baru }\end{array}$} & \multirow{3}{*}{$\begin{array}{l}\text { Penyimpanan } \\
\text { gagal }\end{array}$} & \multirow{3}{*}{$\begin{array}{l}\text { Pengujian sukses, data } \\
\text { gagal disimpan karena } \\
\text { ada field yang kosong }\end{array}$} \\
\hline Judul Kegiatan & Isi & & & \\
\hline Penanggung Jawab & kosong & & & \\
\hline Kode kegiatan & 1804.007 .013 & \multirow{3}{*}{$\begin{array}{l}\text { Sukses menyimpan } \\
\text { data baru }\end{array}$} & \multirow{3}{*}{$\begin{array}{l}\text { Penyimpanan } \\
\text { sukses }\end{array}$} & \multirow{3}{*}{$\begin{array}{l}\text { Pengujian sukses, } \\
\text { karena seluruh field } \\
\text { terisi. }\end{array}$} \\
\hline Judul Kegiatan & Isi & & & \\
\hline Penanggung Jawab & $\begin{array}{l}\text { Dr. Ir. Harwanto, } \\
\text { M.Si }\end{array}$ & & & \\
\hline Kode kegiatan & 1804.007 .013 & \multirow{3}{*}{$\begin{array}{l}\text { Sukses menyimpan } \\
\text { data yang diedit }\end{array}$} & \multirow{3}{*}{$\begin{array}{l}\text { Penyimpanan } \\
\text { sukses }\end{array}$} & \multirow{3}{*}{ Pengujian sukses } \\
\hline Judul Kegiatan & Isi & & & \\
\hline Penanggung Jawab & Ir. Agus Sugiyatno & & & \\
\hline
\end{tabular}

Pada tabel 4 dapat dijelaskan bahwa pengujian insert judul kegiatan dapat digunakan untuk menambahkan judul kegiatan yang baru. Field-field pada form input harus terisi semua tanpa ada yang kosong, agar data yang baru ditambahkan dapat tersimpan dalam database. Update judul kegiatan diperlukan untuk menyesuaikan dengan data terbaru jika ternyata ada perubahan data.

Penghapusan data hanya boleh dilakukan pada saat-saat awal proses penambahan data, jika data tersebut dinyatakan salah. Untuk menghapus judul kegiatan, admin dapat langsung memilih tombol hapus pada view judul kegiatan yang dikehendaki.

\subsubsection{Pengujian Laporan Terkirim}

Pengujian laporan terkirim dimana admin dapat melakukan update data dan delete data, setelah laporan tahapan rencana kegiatan telah dikirim oleh user (peneliti) yang dapat dilihat melalui view detil pada laporan terkirim. Kegiatan pengujian sistem meliputi update yang terdapat pada tabel 5 .

Tabel 5. Pengujian update tahapan kegiatan pada laporan terkirim

\begin{tabular}{|c|c|c|c|c|c|}
\hline \multicolumn{6}{|c|}{ Kasus dan Hasil Uji } \\
\hline \multicolumn{3}{|c|}{ Data Masukan } & \multirow{2}{*}{$\begin{array}{c}\text { Yang } \\
\text { Diharapkan }\end{array}$} & \multirow{2}{*}{$\begin{array}{c}\text { Hasil } \\
\text { Pengujian }\end{array}$} & \multirow{2}{*}{ Kesimpulan } \\
\hline No & Variabel & Perubahan & & & \\
\hline \multirow{2}{*}{1.} & $\begin{array}{l}\text { Tahapan } \\
\text { kegiatan }\end{array}$ & isi & \multirow{2}{*}{$\begin{array}{l}\text { Sukses } \\
\text { menyimpan } \\
\text { data yang } \\
\text { diedit }\end{array}$} & \multirow[t]{2}{*}{$\begin{array}{l}\text { Penyimpa } \\
\text { nan sukses }\end{array}$} & \multirow{2}{*}{$\begin{array}{l}\text { Pengujian } \\
\text { sukses }\end{array}$} \\
\hline & Bobot & isi & & & \\
\hline
\end{tabular}

\subsection{Pengujian sistem pada user (peneliti)}

\subsubsection{Pengujian sistem login}

Kegiatan pengujian sistem login pada user sama seperti sistem login pada admin. Pengujian dilakukan dengan memasukkan beberapa variasi pengujian. Variasi pengujian sistem login dapat dilihat pada tabel 6. 


\begin{tabular}{|c|c|c|c|c|c|}
\hline \multicolumn{6}{|c|}{ Kasus dan Hasil Uji } \\
\hline \multicolumn{3}{|c|}{ Data Masukan } & $\begin{array}{c}\text { Yang } \\
\text { Diharapkan }\end{array}$ & $\begin{array}{c}\text { Hasil } \\
\text { Pengujian }\end{array}$ & Kesimpulan \\
\hline No & Variabel & Masukan & & & \\
\hline 1. & $\begin{array}{l}\text { Nama } \\
\text { Kata } \\
\text { Kunci } \\
\end{array}$ & $\begin{array}{l}\text { kosong } \\
\text { kosong }\end{array}$ & Login gagal & $\begin{array}{l}\text { Login } \\
\text { gagal }\end{array}$ & $\begin{array}{l}\text { Pengujian } \\
\text { sukses }\end{array}$ \\
\hline 2. & $\begin{array}{l}\text { Nama } \\
\text { Kata } \\
\text { Kunci }\end{array}$ & $\begin{array}{l}\text { kosong } \\
\text { emi }\end{array}$ & Login gagal & $\begin{array}{l}\text { Login } \\
\text { gagal }\end{array}$ & $\begin{array}{l}\text { Pengujian } \\
\text { sukses }\end{array}$ \\
\hline 3. & $\begin{array}{l}\text { Nama } \\
\text { Kata } \\
\text { Kunci }\end{array}$ & $\begin{array}{l}\text { emi } \\
\text { kosong }\end{array}$ & Login gagal & $\begin{array}{l}\text { Login } \\
\text { gagal }\end{array}$ & $\begin{array}{l}\text { Pengujian } \\
\text { sukses }\end{array}$ \\
\hline 4. & Nama & emi & Login sukses & $\begin{array}{l}\text { Login } \\
\text { sukses }\end{array}$ & $\begin{array}{l}\text { Pengujian } \\
\text { sukses }\end{array}$ \\
\hline & $\begin{array}{l}\text { Kata } \\
\text { Kunci }\end{array}$ & emi & & & \\
\hline
\end{tabular}

Dapat dijelaskan bahwa pengujian sistem login pada tabel 6 digunakan untuk mengetahui bagaimana user dapat masuk ke halaman utama aplikasi. Untuk dapat masuk ke halaman utama terlebih dahulu user harus terdaftar di dalam database aplikasi.

\subsubsection{Pengujian Data Pegawai (profil)}

Halaman data pegawai pada user hanya menampilkan data pribadi user yang melakukan login. User memiliki hak akses untuk melakukan update data yang ada jika ada perubahan data terbaru. Pengujian data pegawai pada user hanya menguji update data pegawai. Kegiatan pengujian sistem update terdapat pada tabel 7.

Tabel 7. Pengujian update data pegawai (profil)

\begin{tabular}{|c|c|c|c|c|}
\hline \multicolumn{5}{|c|}{ Kasus dan Hasil Uji } \\
\hline \multicolumn{2}{|c|}{ Data Masukan } & \multirow{2}{*}{$\begin{array}{c}\text { Yang } \\
\text { Diharapkan }\end{array}$} & \multirow{2}{*}{$\begin{array}{c}\text { Hasil } \\
\text { Pengujian }\end{array}$} & \multirow{2}{*}{ Kesimpulan } \\
\hline Variabel & Masukan & & & \\
\hline NIP & $\begin{array}{l}20170530.201706 \\
.1 .013\end{array}$ & \multirow{7}{*}{$\begin{array}{l}\text { Sukses } \\
\text { menyimpan } \\
\text { update data }\end{array}$} & \multirow{7}{*}{$\begin{array}{l}\text { Penyimpanan } \\
\text { sukses }\end{array}$} & \multirow{7}{*}{$\begin{array}{l}\text { Pengujian sukses, } \\
\text { karena seluruh field } \\
\text { terisi. }\end{array}$} \\
\hline $\begin{array}{l}\text { Nama } \\
\text { Pegawai }\end{array}$ & baru & & & \\
\hline Jabatan & peneliti & & & \\
\hline $\begin{array}{l}\text { No. } \\
\text { Telephone }\end{array}$ & 0813555777333 & & & \\
\hline Username & baru & & & \\
\hline Password & baru & & & \\
\hline Hak Akses & peneliti & & & \\
\hline
\end{tabular}

Pada tabel 7 dapat dijelaskan bahwa pengujian update data pegawai dapat digunakan untuk merubah data pegawai bilamana diperlukan. Field-field pada form update harus terisi semua tanpa ada yang kosong, agar data yang baru dirubah dapat tersimpan dalam database. Update data pegawai diperlukan untuk menyesuaikan dengan data terbaru jika ternyata ada perubahan data dan hal ini dapat dilakukan sendiri oleh user. Untuk melakukan perubahan data pegawai, user dapat langsung memilih tombol ganti pada view data pegawai Balitjestro.

\subsubsection{Pengujian Judul Kegiatan}

Pengujian judul kegiatan dilakukan untuk menguji proses input dalam mengisi tahapan rencana kegiatan sebagai bahan laporan user yang akan dikirimkan. Pengujian sistem dapat dilihat pada tabel 3.8 Pengujian dilakukan untuk proses penjumlahan otomatis pada cell subtotal, serta proses penyimpanan data yang telah di-input-kan dalam form tahapan rencana kegiatan 
Tabel 8. Pengujian input rencana tahapan kegiatan pada judul kegiatan

\begin{tabular}{|c|c|c|c|c|c|}
\hline \multicolumn{6}{|c|}{ Kasus dan Hasil Uji } \\
\hline \multicolumn{3}{|c|}{ Data Masukan } & $\begin{array}{c}\text { Yang } \\
\text { Diharapkan }\end{array}$ & $\begin{array}{c}\text { Hasil } \\
\text { Pengujian }\end{array}$ & Kesimpulan \\
\hline No & Variabel & Masukan & & & \\
\hline \multirow[b]{2}{*}{1.} & Tahapan kegiatan & Isi & & & \\
\hline & Bobot bulanan (jan-des) & $\begin{array}{l}\text { Ada yang } \\
\text { kosong }\end{array}$ & Subtotal kosong & Subtotal kosong & $\begin{array}{l}\text { Pengujian } \\
\text { berhasil }\end{array}$ \\
\hline \multirow[b]{2}{*}{2.} & Tahapan kegiatan & Isi & & & \\
\hline & Bobot bulanan (jan-des) & Isi & Subtotal isi & Subtotal isi & $\begin{array}{l}\text { Pengujian } \\
\text { berhasil }\end{array}$ \\
\hline \multirow[t]{2}{*}{3.} & Tahapan kegiatan & Isi & \multirow[t]{2}{*}{$\begin{array}{l}\text { Sukes } \\
\text { menyimpan }\end{array}$} & $\begin{array}{l}\text { Sukes } \\
\text { menyimpan }\end{array}$ & \multirow[t]{2}{*}{$\begin{array}{l}\text { Pengujian } \\
\text { berhasil }\end{array}$} \\
\hline & Bobot bulanan (jan-des) & Isi & & & \\
\hline
\end{tabular}

\section{KESIMPULAN DAN SARAN}

Berdasarkan pembahasan, evaluasi dan penelitian yang telah dilakukan, maka dapat disimpulkan bahwa dengan terciptanya aplikasi Monitoring Pelaporan Perkembangan Kegiatan Penelitian berbasis web dapat membantu admin dalam memonitor laporan rencana kegiatan penelitian yang sudah dan yang belum terkirim, melalui halaman menu laporan terkirim. User juga dimudahkan dalam penyampaian laporan rencana kegiatan karena dapat dikerjakan dan dikirim tanpa meninggalkan ruangan sehingga dapat menghemat waktu. Rencana kegiatan yang disimpan user merupakan "laporan" yang diterima admin.

Beberapa saran untuk memperbaiki kekurangan dan untuk perkembangan dari sistem yang telah dibuat, yaitu perlu ditambahkan :

fitur halaman petunjuk, halaman ini diharapkan dapat membantu user dalam memahami aplikasi monitoring, fitur berikutnya adalah perlu ada tambahan laporan perkembangan, laporan pelaksanaan kegiatan, sehingga dapat juga memonitor kinerja peneliti dari sisi ketepatan dan manajemen penyelesaian laporan dan yang terakhir perlu adanya tambahan halaman cetak laporan.

\section{DAFTAR PUSTAKA}

Afrianto, I., \& Setiyadi, A. (2019). Sistem Informasi Monitoring Perdagangan Pariwisata dan Investasi di Indonesia dengan Negaranegara di Kawasan Amerika dan Eropa. Informatics for Educators and Professionals, 3(2).

Badan Penelitian dan Pengembangan Pertanian. (2013). Badan Penelitian dan Pengembangan Pertanian. 2013. Panduan Manajemen Korporasi, Badan Penelitian dan Pengembangan Pertanian. Jakarta: Badan Penelitian dan Pengembangan Pertanian.

http://www.litbang.pertanian.go.id/buku/pa nduan-cms/

Cortinas, A., Luaces, M. R., Pedreira, O., Places, A. S., \& Perez, J. (2017). Web based geographic informatioon systems SPLE: Domain Analysis and Experience Report. Proceeddings SPLC, A, 190.

Daniel, Parningotan, \& Suwarni, E. (n.d.). Pengaruh Minat, Kebermanfaatan dan Kemudahan E-

Form terhadap Tingkat Kepatuhan Pelaporan Surat Pemberitahuan Tahuna [Thesis]. Bina Darma. http://repository.binadarma.ac.id/1113/

Eka Kumala, A., Borman, R. I., \& Prasetyawan, P. (n.d.). Sistem Informasi Monitoring Perkembangan Sapi di Lokasi Uji Performance (studi kasusu: Dinas Peternakan dan Kesehatan Hewan Provinsi Lampung). Jurnal TEKNOKOMPAK, $12(1)$.

Firdaus, \& Afriyan, F. (2011). Rancang bangun sistem monitoring perkuliahan Berbasis web di Fakultas Ilmu Komputer Universitas Sriwijaya. Seminar Nasional Hasil Penelitian.

Haryono, K., Asa Firdausi, F. A., \& Hendrik. (n.d.). Sistem Informasi Monitoring Wiraniaga (studi kasus di UD. Super Dangsul. Jurnal Masyarakat Informatika, 1(1'), 21-35.

Heli Setyawan, Y., \& Munari, A. S. (2020). Membangun Sistem Monitoring Kinerja Mahasiswa Internship Berbasis Web dan Global Positioning System.

leonove, S., \& Boiko, A. (2019). Prototyping of Information System for Monitoring Banking Transactions related to Money Laudering. SHS Web of Conferences, 7. https://oi.org/10.1051/shsconf/201965040 13

Mardiani, G. T. (2013). Sistem Monitoring Data Aset dan Inventaris PT. Telkom Cianjur Berbasis Web. Jurnal Ilmiah Komputer Dan Informatika, 2(1).

Monitoring Dokumen Laporan (4th ed., p. 926). (2008).

Mudjahidin, \& Dita Pahang Putra, N. (2010). Rancang Bangun Sistem Informasi Monitoring Perkembangan Proyek Berbasis 
Web Studi Kasus di Dinas Bina Marga dan Pemantusan. Jurnal Teknis Industri, 11(1).

Nurhayati, S., \& Feliciano Waha, L. (2012). Pemodelan Monitoring Distribusi Bantuan Bencana Alam Berbasis Web. Jurnal Sistem Komputer Unikon Komputika, 1(2).

Perezgonzalez, J. D. (2005). Construction Safety Management, A Systems Approach-Page 80.

Rizal HIkmah, R., \& Andarsyah, R. (2020). Tutorial pembuatan aplikasi monitoring system EPPM go! 